\title{
PI CONTROLLER WITH NEURAL NETWORK ADJUSTMENT FOR SPEED REGULATION IN BRUSHLESS DIRECT CURRENT MOTOR
}

\author{
Yasin Bektaş ${ }^{1}$, Hulusi Karaca ${ }^{2}$ and Taner Dindar $^{3}$ \\ ${ }^{1}$ Technical Sciences Vocational High School Department of Electrical-Energy, \\ Aksaray University, Aksaray, Turkey \\ e-mail: yasinbektas@aksaray.edu.tr \\ ${ }^{2}$ Technology Faculty, Electrical-Electronics Engineering, \\ Selçuk University, Konya, Turkey \\ e-mail: hkaraca@selcuk.edu.tr \\ ${ }^{3}$ Nallıhan Vocational High School, \\ Ankara University, Ankara, Turkey \\ e-mail: tanerdindar@ankara.edu.tr
}

\begin{abstract}
Brushless DC motor (BLDCM) has been widely used in many different fields such as high efficiency and dynamic response and high speed range in recent years. Since the BLDC motor driver does not behave, it is complex to control it via the proportional-integral (PI) controller. In this article, the mathematical model of the BLDC motor and artificial neural network algorithm is derived to make the BLDC motor control. On the proposed drive, the controller synchronizes quickly with speed, learning the motor speed to follow and load quickly. The effectiveness of the proposed method is demonstrated by the model developed in MATLAB / Simulink. The simulation results show that the proposed artificial neural network controller provides a significant improvement in control performance compared to the PI controller for both control reference speed changes and load changes.
\end{abstract}

Keywords: BLDC Motor, ANN Controller, Proportional Integral Derivative (PID) Controller.

\section{INTRODUCTION}

Brushless Direct Current (BLDC) motors outperforms other motors with its high efficiency, high power factor, precise speed and torque control, and low maintenance requirements. The FSDA motor has gained importance mainly in applications such as electric trains, electric automotive, aviation and robotics [1]. Conventional controllers (PID and PI) are often used for control actions in different engineering tasks. These are constant gain control devices and require a precise process model for their designs. Brushless dc motor is a nonlinear motor and it is often difficult to provide a complete mathematical model. In addition, the internal parameters such as resistance and inertia of the motor are separated from their actual values, respectively, depending on the ambient temperature conditions and the changes in the increasing load conditions [1-2]. Conventional control devices exhibit degraded performance due to this change in the internal parameters of the motors. This has led researchers to explore intelligent and adaptive controllers that can perform satisfactorily under a variety of conditions. The model reference adaptive control technique is among the various approaches available for adaptive control $[\mathrm{x}]$. Model reference adaptive control technique is among the various approaches available for adaptive control. The standard idea behind model reference adaptive control is to design a closed loop controller with adjustable parameters so that the behavior of the plant being inspected follows the behavior of a reference model. Artificial Neural Networks (ANN) have a tremendous scope in control system applications due to the numerous advantages offered by them. Its high learning trait 


\section{AR'IIL}

Ipplied Researleches in Technics, Technologies and Educration

Journal of the Faculty of Technics and Technologies, Trakia University https:///ites.google.com/a/trakia-uni.bg/artte/

and non-linear mapping features offer a desired non-linear mapping for an electric drive without going into the system complexity.

\section{MODELLING}

The modeling of the Permanent magnet BLDC motor is discussed in [3,5]. In armature control of independently excited BLDC motor, the voltage applied to the motor armature is adjusted without changing the applied voltage to the field. Figure 1 shows a BLDC motor equivalent model.

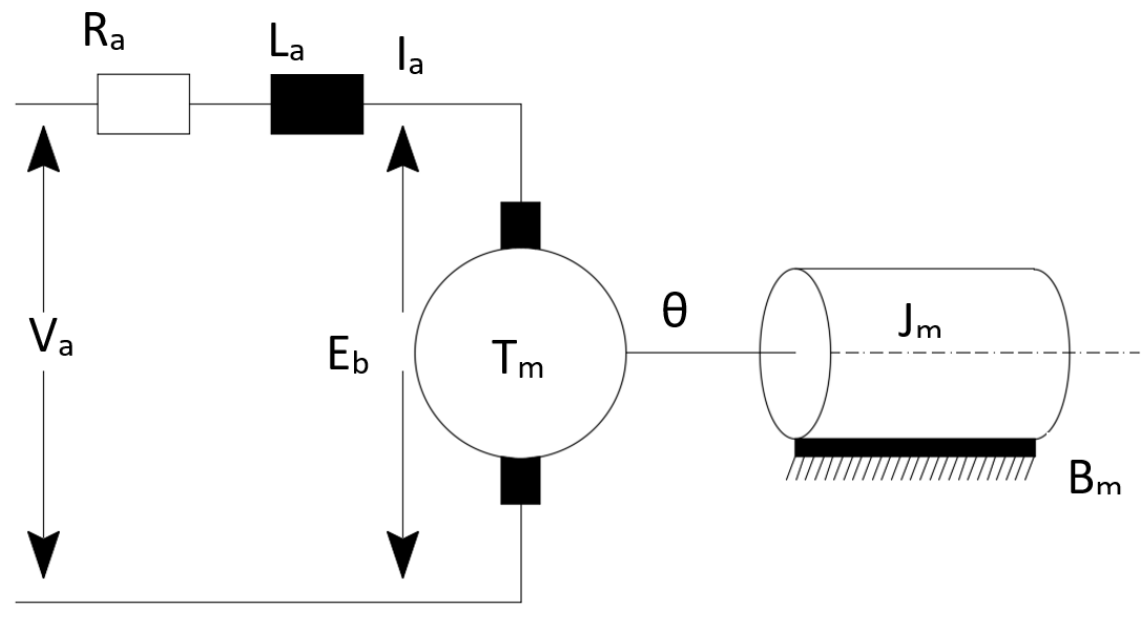

Figure 1. BLDC Motor Model: $\mathrm{Va}=$ armature voltage $(\mathrm{V}) ; \mathrm{a}=$ armature resistance $(\Omega) ; \mathrm{La}=$ armature inductance $(\mathrm{H}) ; \mathrm{i}=$ armature current $(\mathrm{A}) ; \mathrm{eb}=\mathrm{Back} \mathrm{EMF}(\mathrm{V}) ; \omega=$ angular speed $(\mathrm{rad} / \mathrm{sec}) ; \mathrm{Tm}=$ motor torque $(\mathrm{Nm}) ; \mathrm{TI}=$ load torque $(\mathrm{Nm}) ; \Theta=$ angular position of rotor shaft

(rad); $\mathrm{Jm}=$ rotor inertia $\left(\mathrm{kg} / \mathrm{m}^{2}\right) ; \mathrm{Bm}=$ friction coefficient $(\mathrm{Nms} / \mathrm{rad}) ; \mathrm{K}=$ torque constant

$(\mathrm{Nm} / \mathrm{A}) ; \mathrm{Kb}=$ Back EMF constant $(\mathrm{Vs} / \mathrm{rad})$

$$
\begin{aligned}
& \omega \propto \frac{\left(V_{a}-i_{a} R_{a}\right)}{\phi} \\
& \omega=\frac{\left(V_{a}-i_{a} R_{a}\right)}{K_{a} \phi}
\end{aligned}
$$

Where:

ф is the field flux per pole, $\mathrm{Ka}$ is armature constant, $\mathrm{Ka}=\mathrm{PZ} / 2 \mathrm{ma}$

$\mathrm{P}$ is the number of poles, From (2), it is clear that for a BLDC motor there are basically two techniques of speed control. They are:

- Control of the resistance of the armature circuit;

- Control of the armature input voltage.

In this work, speed of the BLDC motor is controlled by manipulating the armature terminal voltage. Some useful relations are

$$
V_{a}=R I_{a}(t)+L_{a} \frac{d i_{a}}{d t}+e_{b}
$$




\section{ARITIE} Ipplied Researreches in Technics, Technologies and Eductation Journal of the Faculty of Technics and Technologies, Trakia University https://sites.google.com/a/trakia-uni.bg/artte/

$$
\begin{aligned}
& e_{b}(t)=K_{b} \cdot \omega(t) \\
& T_{m}(t)=K_{t} \cdot i_{a}(t) \\
& T_{m}(t)-T_{l}(t)=J_{m} \cdot \frac{d \omega(t)}{d t}+B_{m} \omega(t) \\
& T_{l}(t)=\mu \omega^{2}
\end{aligned}
$$

Table 1. Parameters of the BLDC motor

\begin{tabular}{|l|c|}
\hline Description of the parameter & Value \\
\hline Armature inductance $(\mathrm{La})$ & $8.5 \mathrm{e}-3 \mathrm{H}$ \\
\hline Armature resistance $(\mathrm{Ra})$ & $2.875 \Omega$ \\
\hline Armature voltage $(\mathrm{Va})$ & $380 \mathrm{~V}$ \\
\hline Rotor inertia $(\mathrm{Jm})$ & $0.8 \mathrm{e}-6 \mathrm{Kg} . \mathrm{m} 2$ \\
\hline
\end{tabular}

\section{SPEED CONTROL OF BLDC MOTOR}

\subsection{Proportional Integral (PI) Control Controller}

The PI controller has a very simple schematic structure as shown in Figure 2.

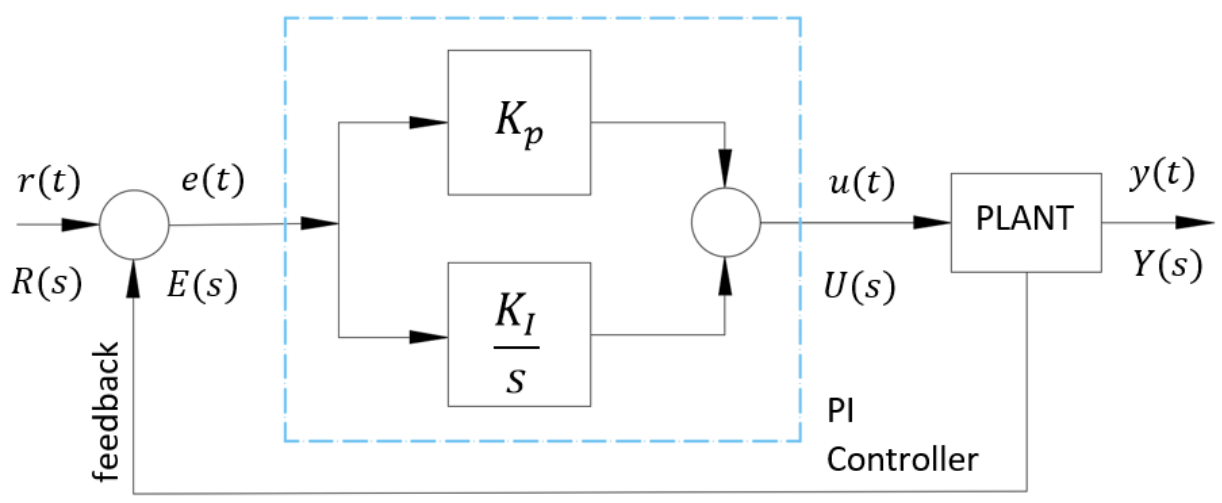

Figure 2. Schematic of PI controller

A variation of Proportional Integral Derivative (PID) control is to use only the proportional and integral terms as $\mathrm{PI}$ control. The $\mathrm{PI}$ controller is the most popular variation, even more than full PID controllers. The value of the controller output $u(t)$ is fed into the system as the manipulated variable input.

$$
\begin{aligned}
& u(t)=u_{\text {bias }}+K_{p} e(t)+K_{I} \int_{0}^{t} e(t) d t \\
& \frac{u(s)}{E(s)}=K_{p}+\frac{K_{I}}{s}=\frac{s K_{p}+K_{I}}{s}=K_{p}\left(1+\left(\frac{K_{I}}{s K_{p}}\right)\right)
\end{aligned}
$$




\section{IRTIIE} Ipplied Reserer rhes in Technics, Technologies and Bduration Journal of the Faculty of Technics and Technologies, Trakia University https://sites.google.com/a/trakia-uni.bg/artte/

$$
\mathrm{Ti}=\frac{K_{p}}{K_{I}}
$$

Domain of the $t u(t)$ is $K_{p} e(t)$.

Domain of the $s u(s)$ is $K_{p} E(s)$.

Where $\mathrm{Kp}$ is the proportional gain, $\mathrm{Ki}$ is the integration coefficient. $\mathrm{Ti}$ is known as the integral action time or reset time. The values of the gains of the PID controller is calculated using Ziegler- Nichols method, which relies solely on parameters obtained from the system step response [8]. The values of the gain of the PI controller used in the work undertaken here are as shown in Table 2.

Table 2. Values of PI Tuning Parameters

\begin{tabular}{|l|l|l|}
\hline Controller & $\mathrm{Kp}$ & $\mathrm{Ki}$ \\
\hline $\mathrm{PI}$ & 0.0130 & 16.610 \\
\hline
\end{tabular}

The $u_{\text {bias }}$ term is a constant that is typically set to the value of $u(t)$ when the controller is first switched from manual to automatic mode. This gives "bumpless" transfer if the error is zero when the controller is turned on. The two tuning values for a PI controller are the controller gain, $\mathrm{Kp}$ and the integral time constant $\mathrm{Ti}$. The value of $\mathrm{Kp}$ is a multiplier on the proportional error and integral term and a higher value makes the controller more aggressive at responding to errors away from the set point. The set point $(S P)$ is the target value and process variable $(P V)$ is the measured value that may deviate from the desired value. The error from the set point is the difference between the $S P$ and $P V$ and is defined as $e(t)=$ $S P-P V$.

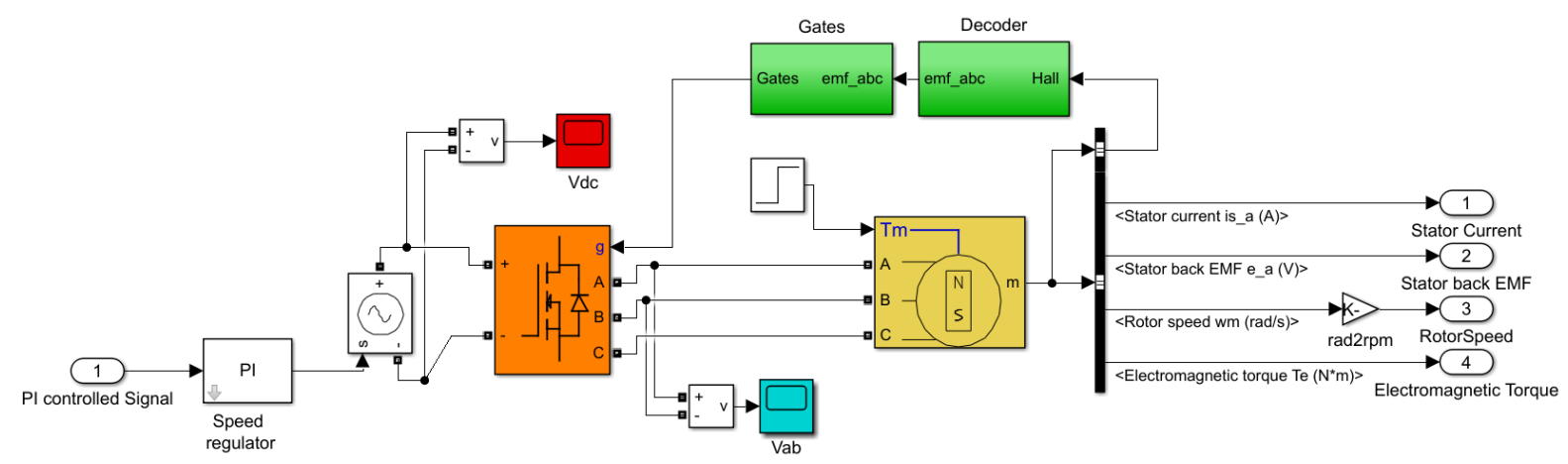

Figure 3. PI Controlled System

Proportional effect integral effect addition removes the permanent state error that occurs in the system if ratio effect is used alone. The integration process removes the persistent state error and reduces the system's response speed under the same relative stability conditions. Increasing the gain of the integral effect increases the response speed, but if the gain value is increased too much, the system may lead to instability.

PI compares the output value of the counter with the reference value and restructures the output speed depending on the error rate. Experimentally, it is not possible to correctly compare the $\mathrm{PI}$ controller with the $\mathrm{NN}$ adjusted $\mathrm{PI}$ counter when the reference speed value is kept for a very short period of time or when it is held for a very long time. We did not show here in order not to exceed the page count of this article. The most favorable results were obtained at the gradual change of the reference speed. 


\section{IRTTIE Ipplied Researreches in Technics, Technologies and Eductation Journal of the Faculty of Technics and Technologies, Trakia University https://sites.google.com/a/trakia-uni.bg/artte/}

\subsection{Model Reference Adaptive Controller (MRAC)}

Artificial neural network has high learning capability. Therefore, it is used for the identification and the control of non-linear systems [9-10]. Neural network based MRAC provides promising solution when process parameters vary. This controller has the tendency that the plant response can be guided by a reference model response which gives the desired transient response.

A model that gives the desired transient response specifications is usually taken as the reference model. A first order underdamped transfer function as shown in Figure 4, having excellent step responses and zero steady state error is picked as reference model so that controller can be trained to assign optimal responses.

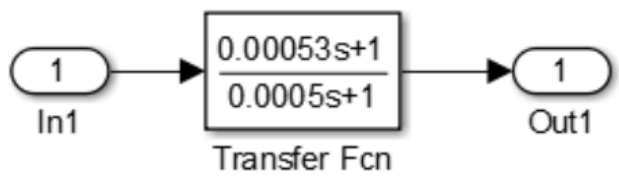

Figure 4. BLDC Motor Reference

The neural model reference control architecture uses two neural networks: a controller network and a system identification network. First the system model is defined and then the controller is trained to follow the output of the reference model. System identifiers use the backpropagation learning algorithm. The system identifier is trained by input-output pairs obtained from the system model. The Levenberg-Marquardt algorithm has been adopted for training the system model. The system identification error is at level $10^{-9}$.

The parameters related to the design and configuration of the system identifier are given in Table 3.

Table 3. Plant Identifier Architecture and Training Parameters

\begin{tabular}{|l|c|}
\hline Size of hidden layer & 12 \\
\hline Sampling interval(s) & 0.1 \\
\hline No. of delayed plant inputs & 2 \\
\hline No. of delayed plant outputs & 2 \\
\hline Training Epochs & 1000 \\
\hline Training Function & trainlm \\
\hline
\end{tabular}

The controller is a recurrent is a recurrent learning multi-layer network. It is trained so that the system response follows the response of the reference model. The BFGS (Broyden, Fletcher, Goldfarb and Shanno) Quasi- Newton algorithm is used for the training of the controller and the performance index was of the order of $10^{-6}$. The parameters associated with the design and tuning of the neural network controller are given in Table 4.

Table 4. Controller Architecture and Training Parameters

\begin{tabular}{|l|c|}
\hline Size of hidden layer & 15 \\
\hline No. of delayed reference inputs & 4 \\
\hline No. of delayed controller outputs & 3 \\
\hline No. of plant outputs & 1 \\
\hline Controller training epochs & 200 \\
\hline Controller training segments & 4 \\
\hline
\end{tabular}

IRTIIE Vol. 6, No. 1, 2018 ISSN 1314-8788 (print), ISSN 1314-8796 (online), doi: 10.15547/artte.2018.01.003 


\section{IRITIE}

Ipplied Reserer rhes in Technics, Technologies and Bduration Journal of the Faculty of Technics and Technologies, Trakia University https://sites.google.com/a/trakia-uni.bg/artte/

\section{SIMULATION RESULTS AND DISCUSSION}

The Simulink model of the BLDC motor under consideration was simulated to know the open loop response of the system. The open loop response of the system is shown in Figure 4. It is clear from the figure that the steady state response of the system is unsatisfactory as the steady state error is 0.5103 much better as compared to the open loop response of the system.

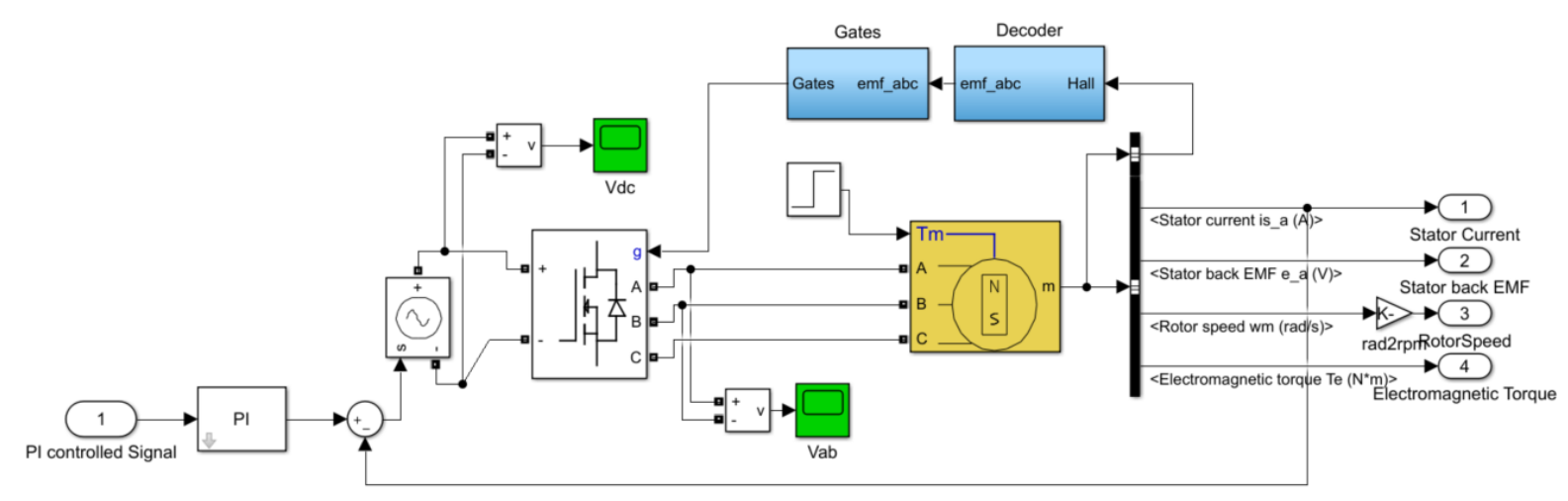

Figure 5. NN Controlled System

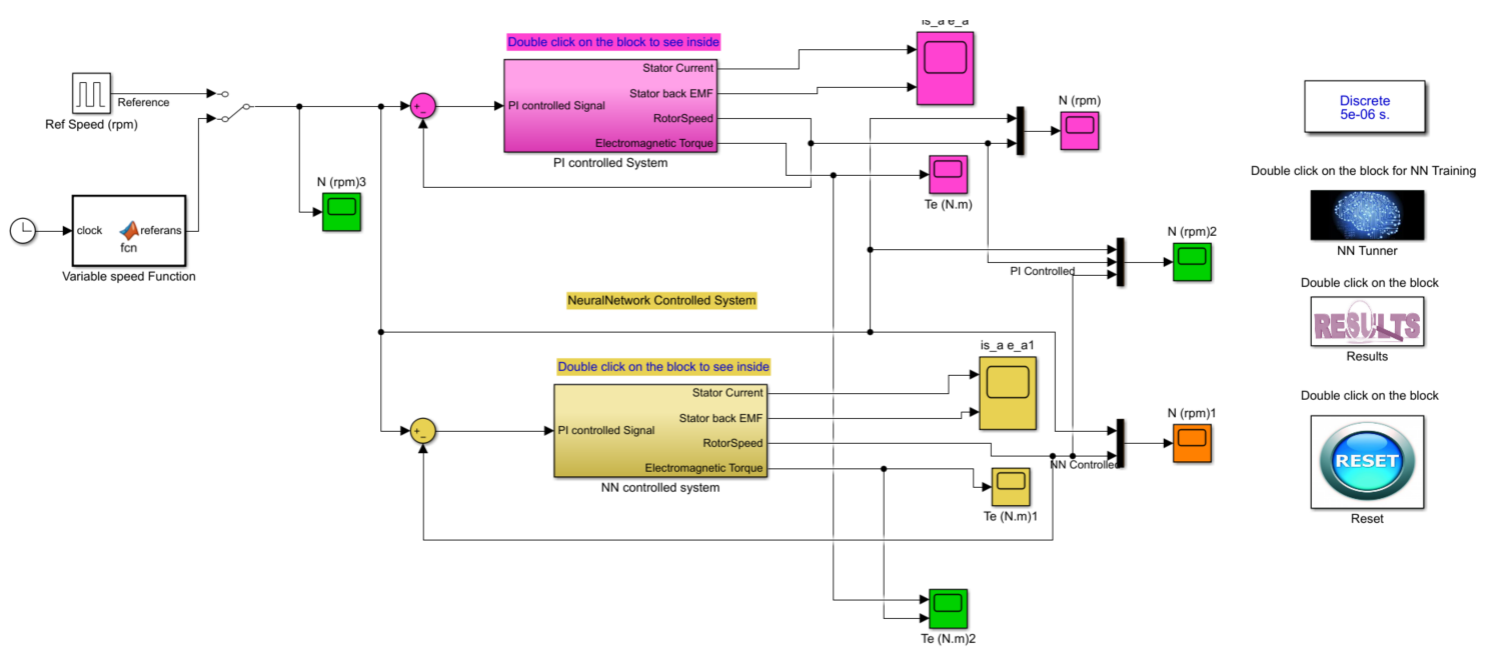

Figure 6. Neural Network Adjusted PI Controlled System

In this section we will consider the modeling of the Neural Network (NN) which is recommended for setting the parameters of the BLDC motor. The BLDC motor simulink model was designed to adjust the engine speed with neural network. The NN model for the BLDC motor was developed. It is stated that the PI controller is used to match the reference speed of the motor. However, it is difficult to comply with proportional and integral gain parameters, test method or some optimization methods. Optimization methods give approximate results, not exact results. To achieve close results, several optimizations must be made and standard deviations of all results should be taken in order to obtain close results. For this reason, the neural network is used to train the PI parameters to obtain the closest results to the reference speed. MATLAB provides a NN toolbox that greatly simplifies

IRTTE Vol. 6, No. 1, 2018 ISSN 1314-8788 (print), ISSN 1314-8796 (online), doi: 10.15547/artte.2018.01.003 


\section{IRITIE

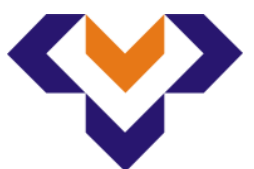

Ipplied Resseirlohes in Technics, Technologies and Eductition

Journal of the Faculty of Technics and Technologies, Trakia University https://sites.google.com/a/trakia-uni.bg/artte/

our work. In order to obtain better results, it should be trained to the capacity of YSA. An FSDA motor reference model in the MATLAB simulink is designed and fed with the reference input speed. This is also true here because every control uses a feedback loop.

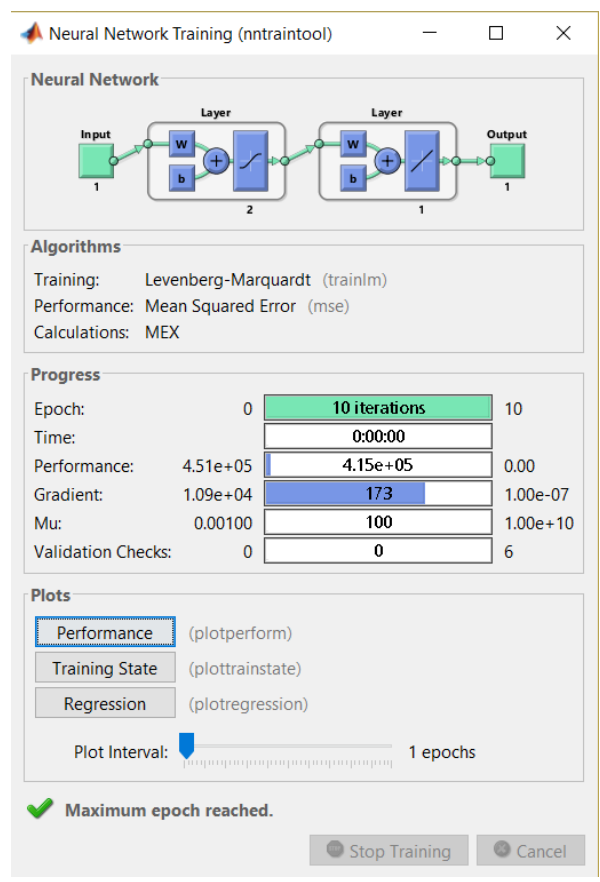

Figure 7. NN Training Process (nntraintool)

Integral gain and proportional gain are started with 16.61 and 0.013 respectively. The form command is compiled using the reference mode, 'sim' with the options defined by 'simset'. With the Levenberg-Marquardt function, a feed-back neural network was created with a feedback loop. Finally, the trained network is used for tests in another model. A comparative diagram of speed and torque is also shown.

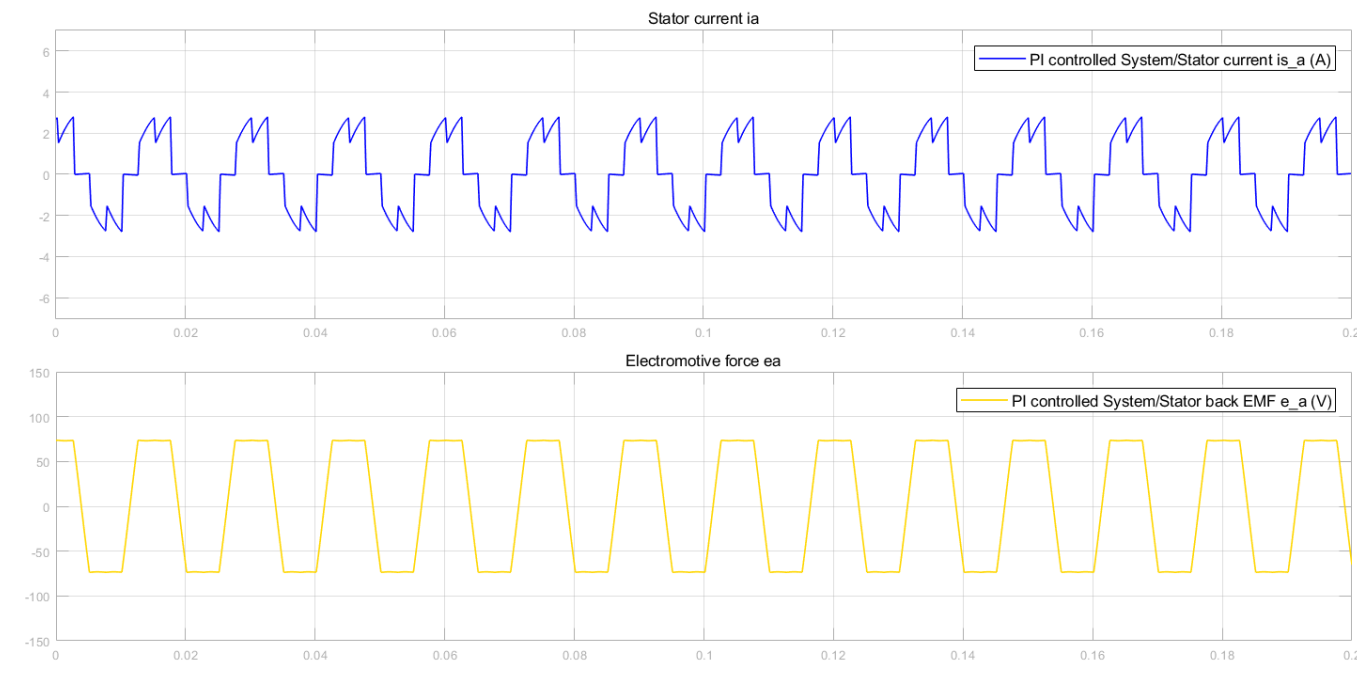

Figure 8a. PI Controller Stator Current and Back EMF (0.2sec)

IRTIIE Vol. 6, No. 1, 2018 ISSN 1314-8788 (print), ISSN 1314-8796 (online), doi: 10.15547/artte.2018.01.003 


\section{IRTTL Ipplied Researrches in Technics, Technologies ind Bducition Journal of the Faculty of Technics and Technologies, Trakia University https://sites.google.com/a/trakia-uni.bg/artte/}

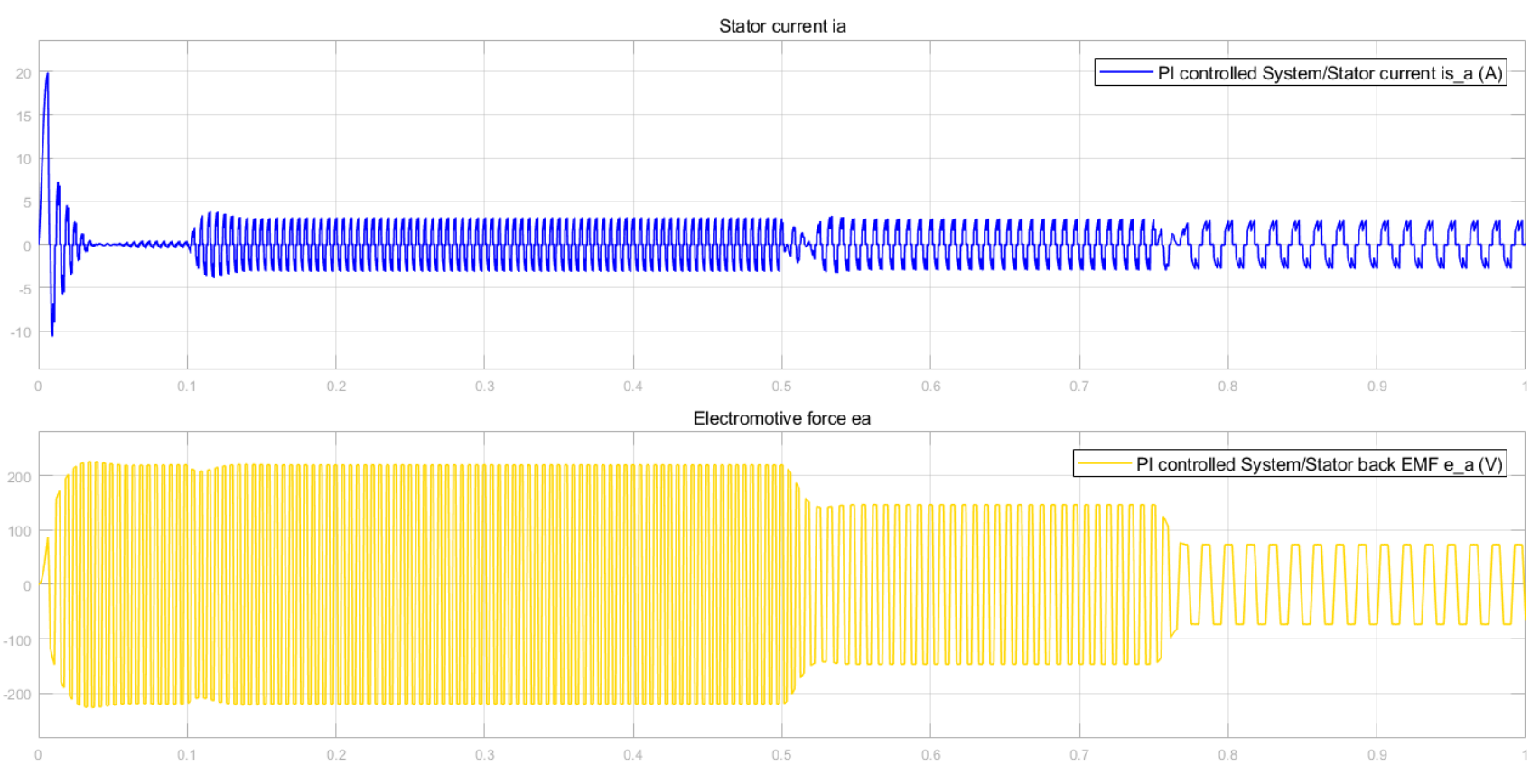

Figure 8b.

PI Controller Stator Current and Back EMF (1sec)

Electromagnetic Torque $(\mathrm{Nm})$

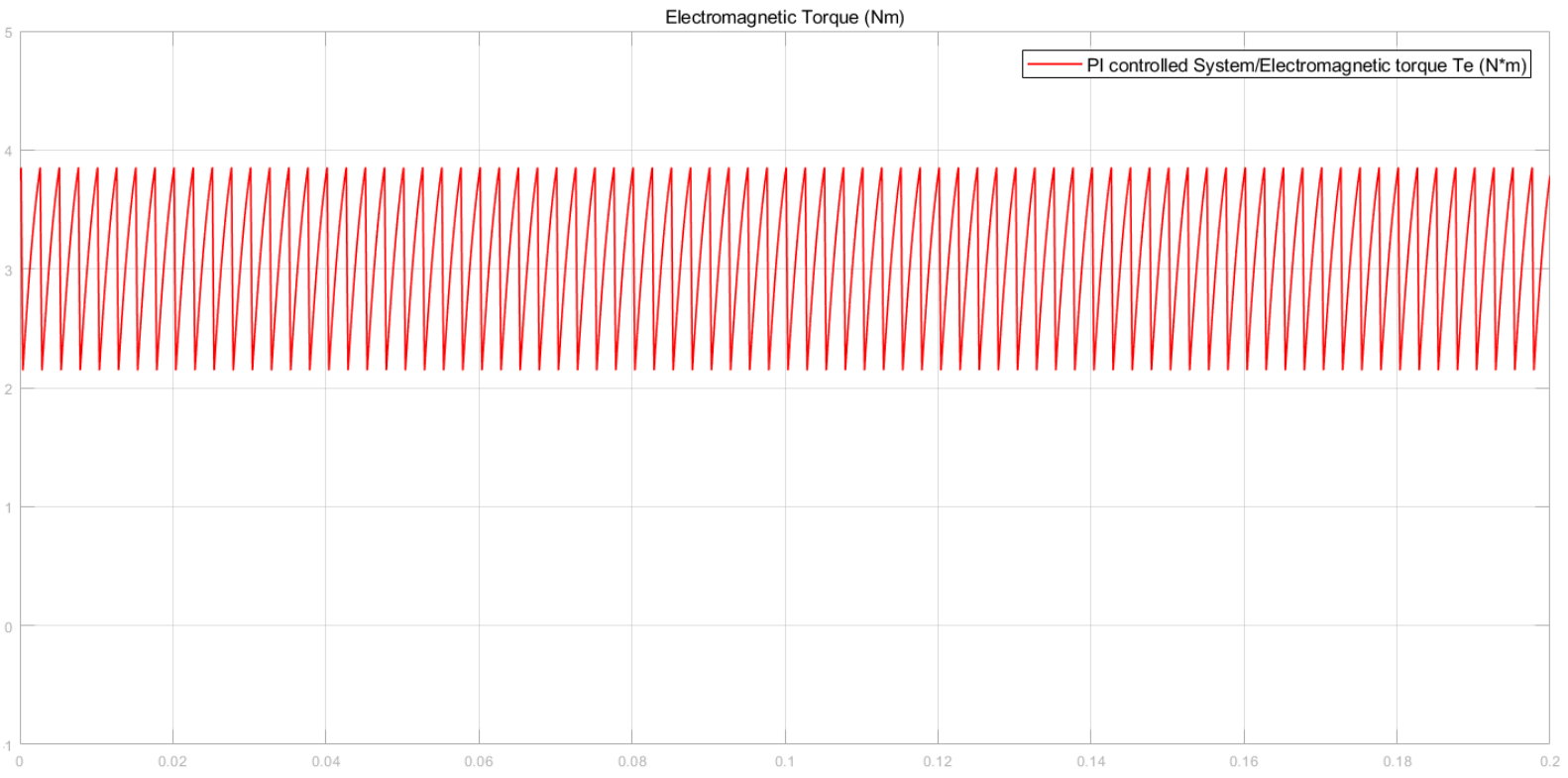

Figure 9a.

PI Controller Electromagnetic Torque (0.2sec)

IRTIIE Vol. 6, No. 1, 2018 ISSN 1314-8788 (print), ISSN 1314-8796 (online), doi: 10.15547/artte.2018.01.003 


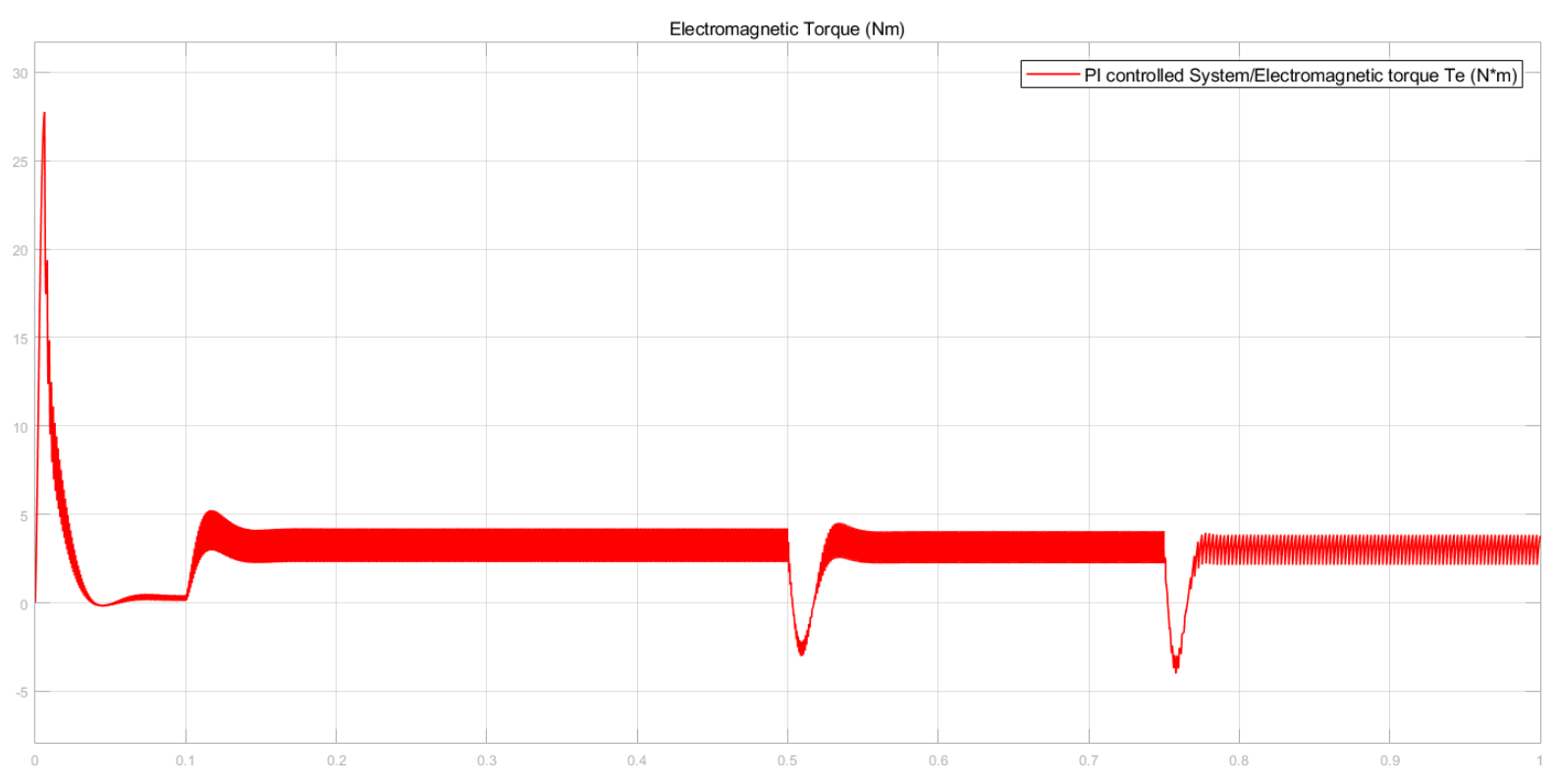

Figure 9b.

PI Controller Electromagnetic Torque (1sec)

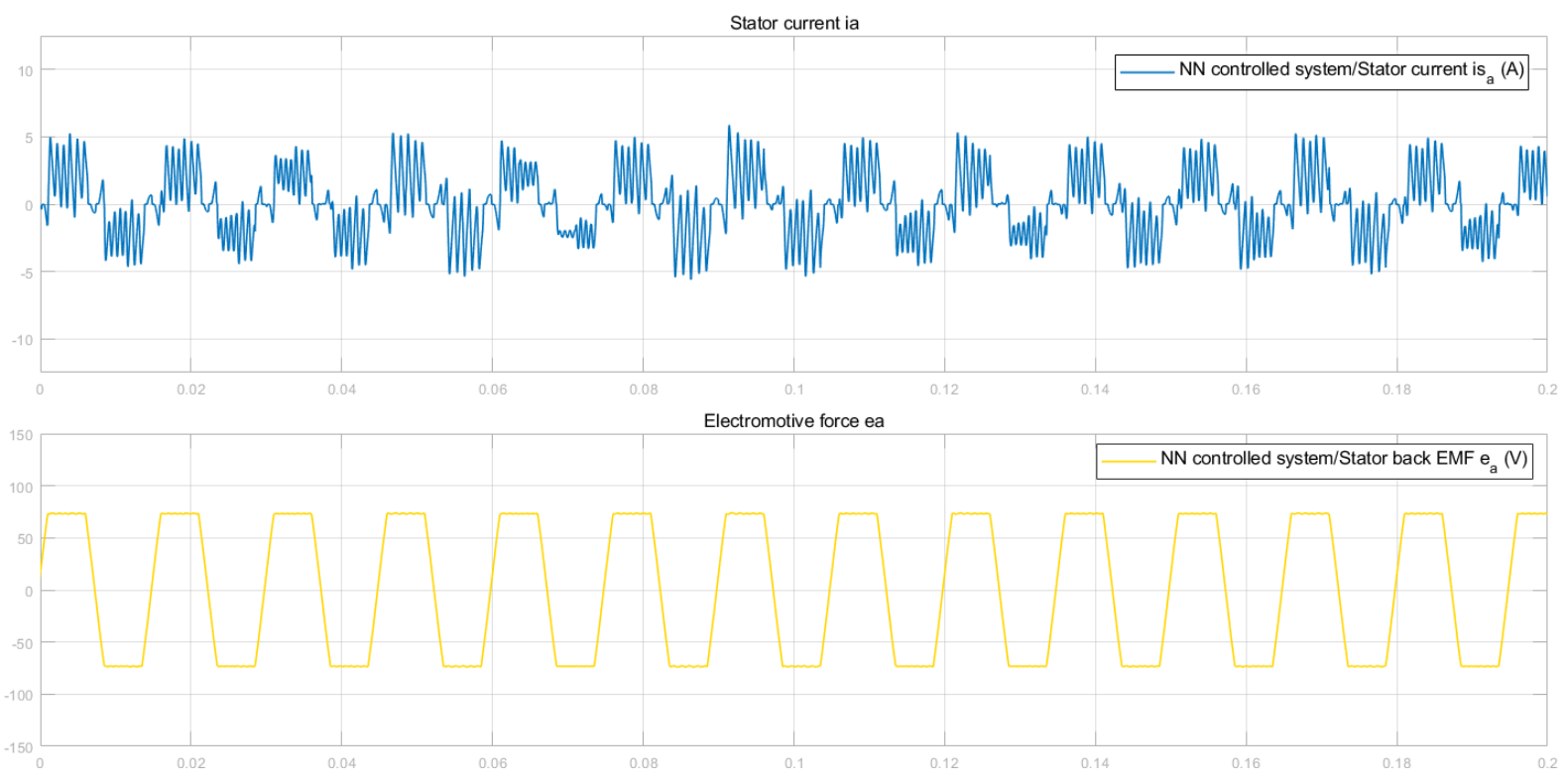

Figure 10a.

NN Controller Stator Current and Back EMF (0.2sec)

IRTIIE Vol. 6, No. 1, 2018 ISSN 1314-8788 (print), ISSN 1314-8796 (online), doi: 10.15547/artte.2018.01.003 


\section{IRTTL

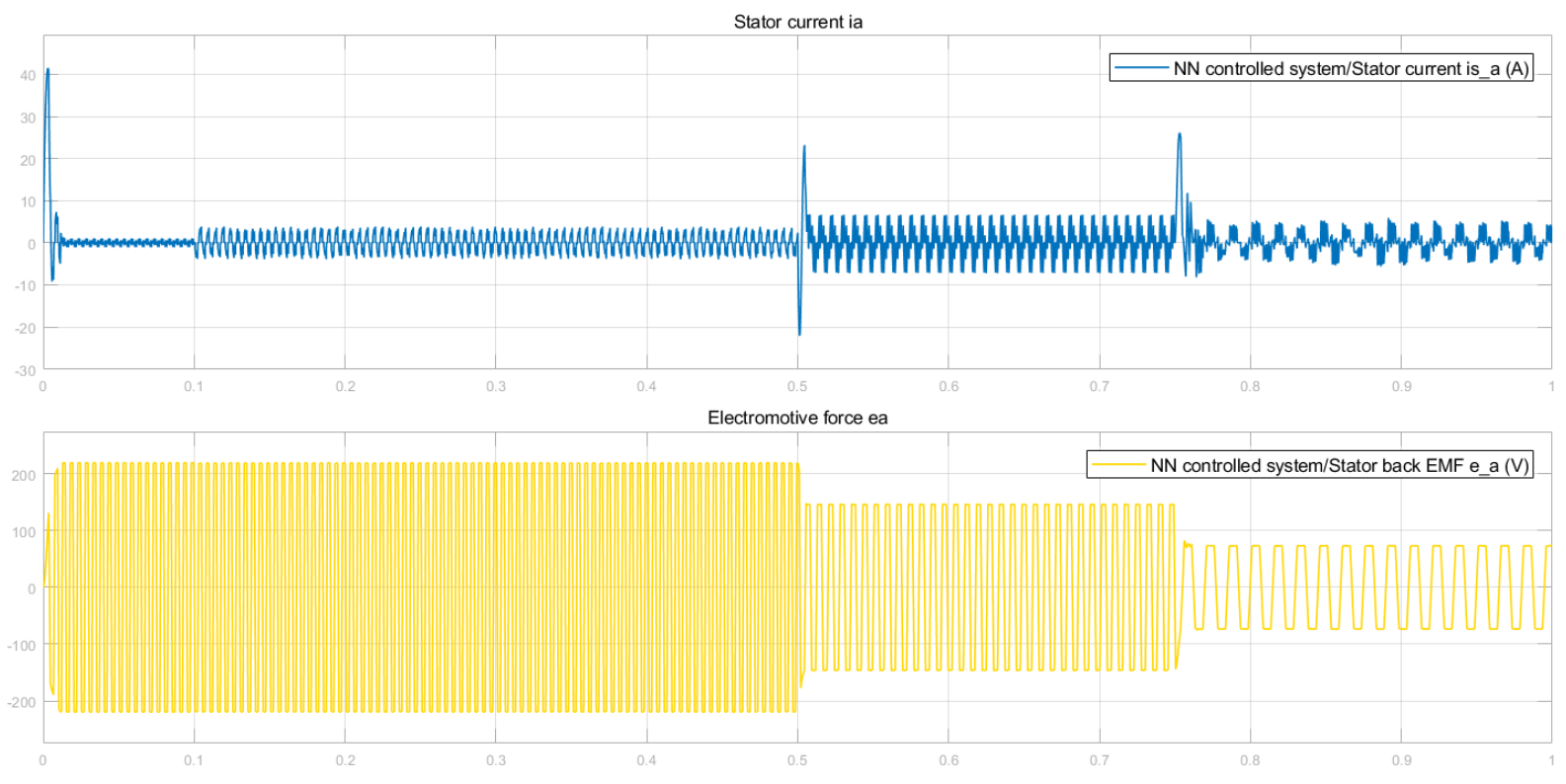

Figure 10b.

NN Controller Stator Current and Back EMF (1sec)

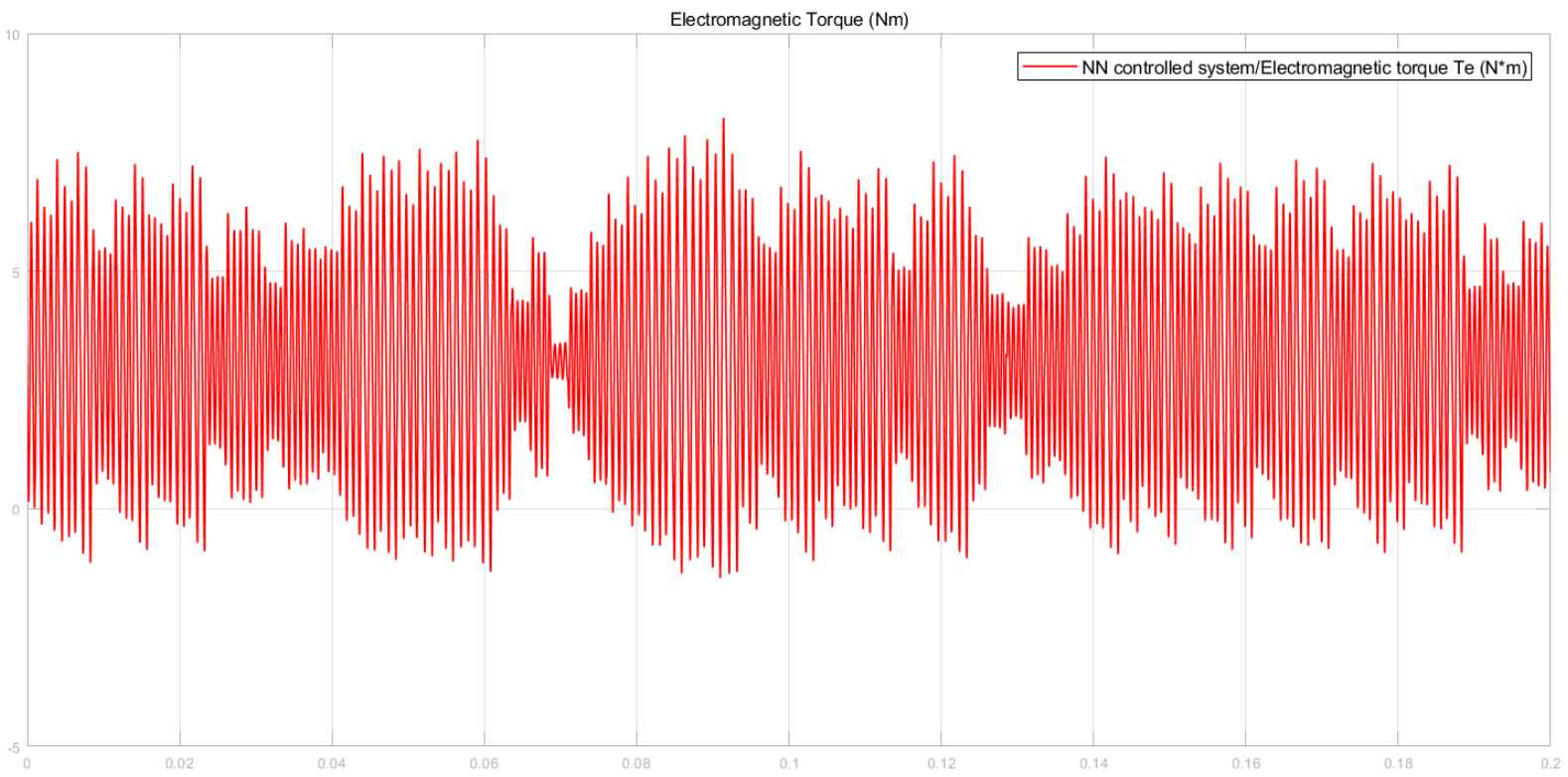

Figure 11a.

NN Controller Electromagnetic Torque (0.2sec)

IRTITE Vol. 6, No. 1, 2018 ISSN 1314-8788 (print), ISSN 1314-8796 (online), doi: 10.15547/artte.2018.01.003 


\section{IRTIL $\\rangle$}

Ipplied Resererr'ches in Technics, Technologies and Bduration Journal of the Faculty of Technics and Technologies, Trakia University https://sites.google.com/a/trakia-uni.bg/artte/

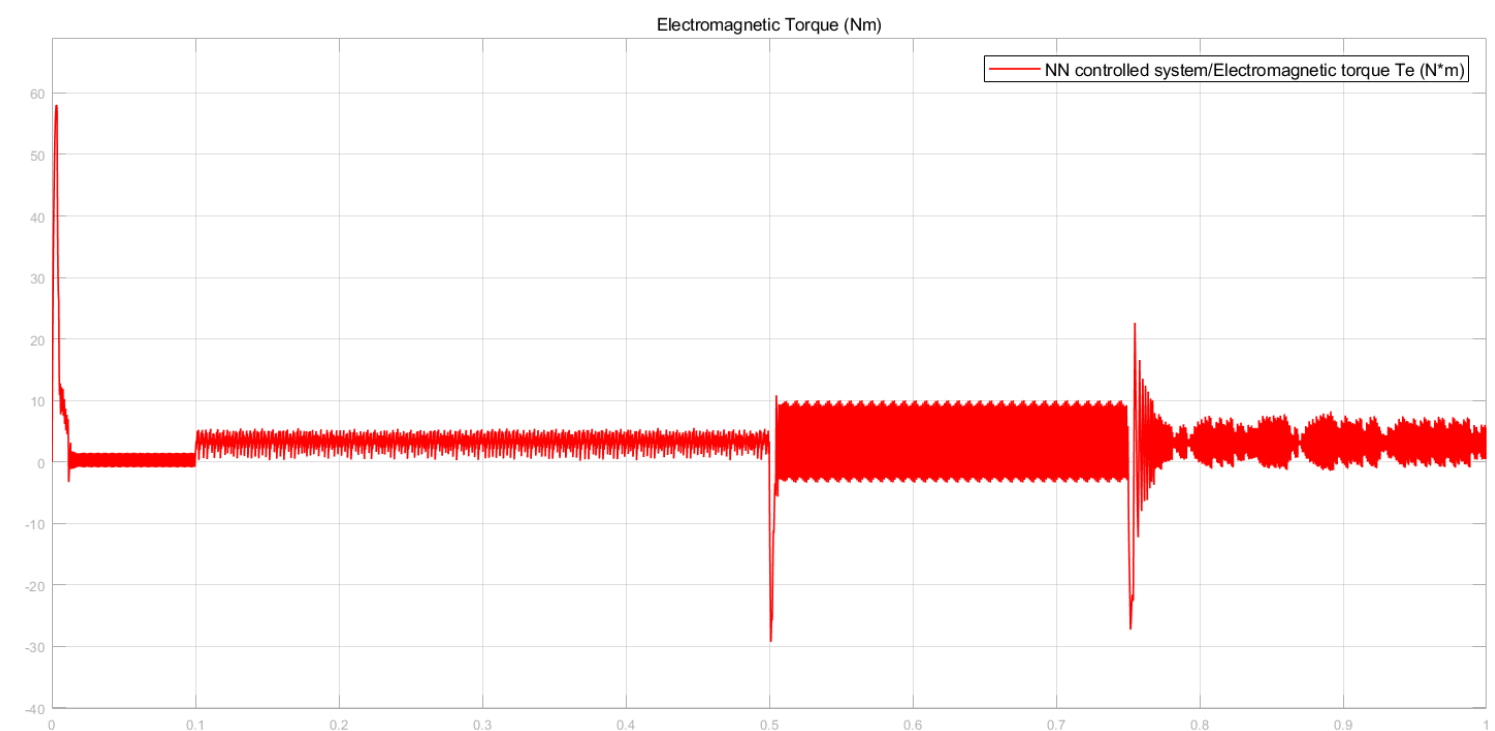

Figure 11b. NN Controller Electromagnetic Torque (1sec)

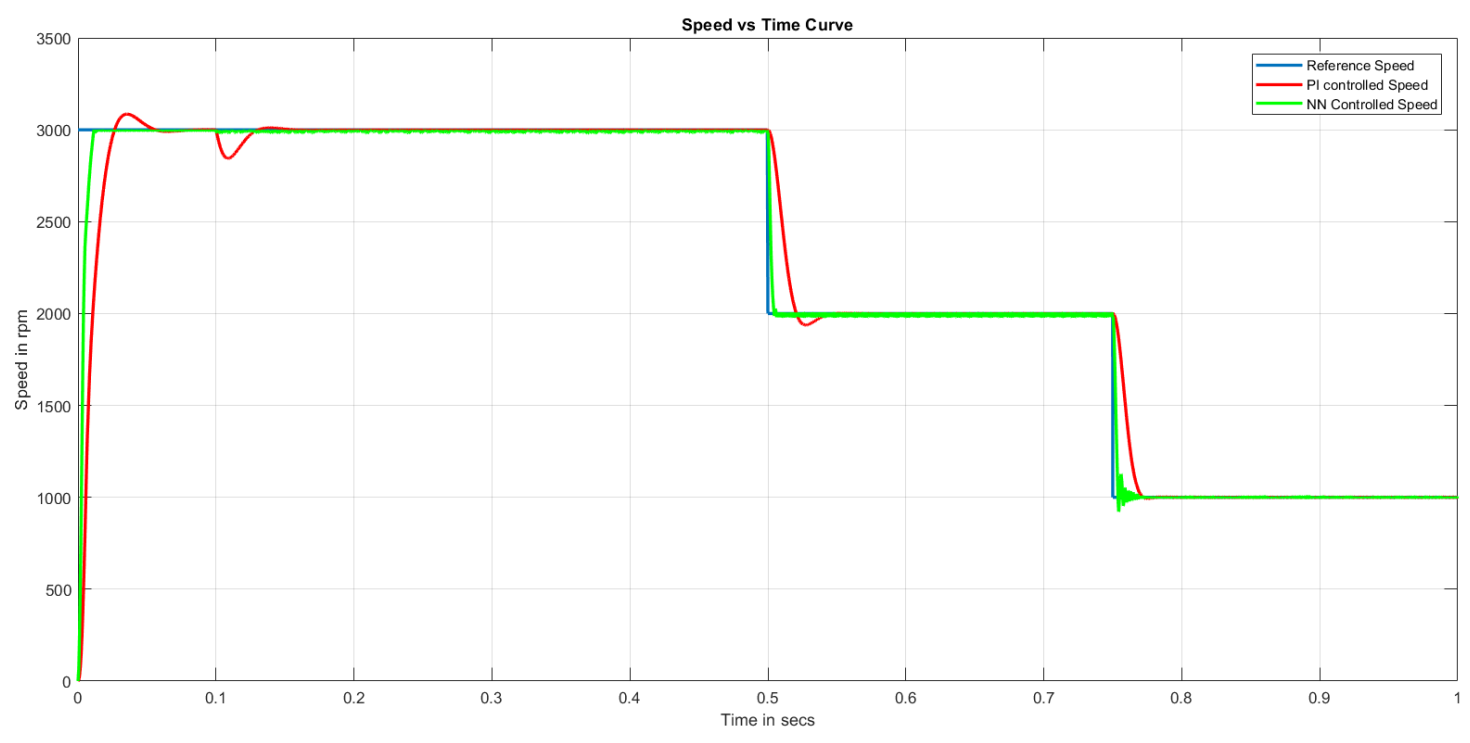

Figure 12. NN-PI Controller Speed Comparison (gradually decreasing speed)

When Figure 12 and Figure 13 are examined as detail: The reference speed is initially 3000 $\mathrm{rpm}$ and the load torque is $2 \mathrm{Nm}$, while the $\mathrm{NN}$ model is sitting at $\mathrm{t}=0.0143 \mathrm{~s}, 3000 \mathrm{rpm}$ and the $\mathrm{PI}$ model is sitting at $3000 \mathrm{rpm}$ at $\mathrm{t}=0.0573 \mathrm{~s}$. When we make a comparison via torque; The NN model $t=0.0033 \mathrm{sn}$ goes to the maximum point of $58.81 \mathrm{Nm}$ and $t=0.038 \mathrm{sn}$ at small fluctuations reaches about $2.24 \mathrm{Nm}$. The PI model tends to reach the maximum point of $\mathrm{t}=$ $0.006 \mathrm{~s}$ at $31.63 \mathrm{Nm}$ and $\mathrm{t}=0.0728$ at small fluctuations to about $2.25 \mathrm{Nm}$. The NN model is not affected much by the load change of $0.25 \mathrm{~s}$. The PI model recovers to a reference speed of 3,000 revolutions per minute at 0.276 seconds. The reference speed between $0.5 \mathrm{~s}$ and $0.75 \mathrm{~s}$ is set to $2000 \mathrm{~s} / \mathrm{min}$. The NN model captures the reference speed $t=0.0505 \mathrm{sn}$ and PI model reaches the reference speed at $t=0,0546 s n$. At $0.5 \mathrm{~s}$ and $0.75 \mathrm{~s}$, the $\mathrm{NN}$ control is affected more quickly than the speed change according to the PI control. PI controller is affected more few and slowly. We made comparison in terms of torque; The NN model $\mathrm{t}=$ IRTTE Vol. 6, No. 1, 2018 ISSN 1314-8788 (print), ISSN 1314-8796 (online), doi: 10.15547/artte.2018.01.003 


\section{ART'TE $Y$}

Ipplied Resseirlores in Technics, Technologies and Educration

Journal of the Faculty of Technics and Technologies, Trakia University https://sites.google.com/a/trakia-uni.bg/artte/

$0.0251 \mathrm{~s}$ to $4.95 \mathrm{Nm}$ maximum $\mathrm{t}=0.026 \mathrm{sn}$ at small fluctuations to about $2.99 \mathrm{Nm}$. The $\mathrm{PI}$ model $\mathrm{t}=0,0268 \mathrm{sn}$ goes to the maximum point of $4.5 \mathrm{Nm}, \mathrm{t}=0.0294$ at small fluctuations to about $3,05 \mathrm{Nm}$. The reference speed between $0.75 \mathrm{~s}$ and $1 \mathrm{~s}$ is set to $1000 \mathrm{rpm}$. The NN model captures the reference speed $t=0.076 \mathrm{sn}$. The $\mathrm{PI}$ model reaches the reference speed at $\mathrm{t}=$ $0.079 \mathrm{sn}$. When we made comparison in terms of torque; The NN model $t=0.0753$ sn goes to the minimum point of $-26.29 \mathrm{~nm}, \mathrm{t}=0.077 \mathrm{sn}$ at small fluctuations to about $3.27 \mathrm{Nm}$. The $\mathrm{PI}$ model $t=0,0758 \mathrm{sn}$ goes to the minimum point of $-3.84 \mathrm{Nm}, t=0.0792$ it fluctuates to about $3.35 \mathrm{Nm}$ at small fluctuations. As a result, the NN Controlled System responds more quickly than the PI Controlled System. More training needs to be provided by NN in order for NN to capture reference speed faster.

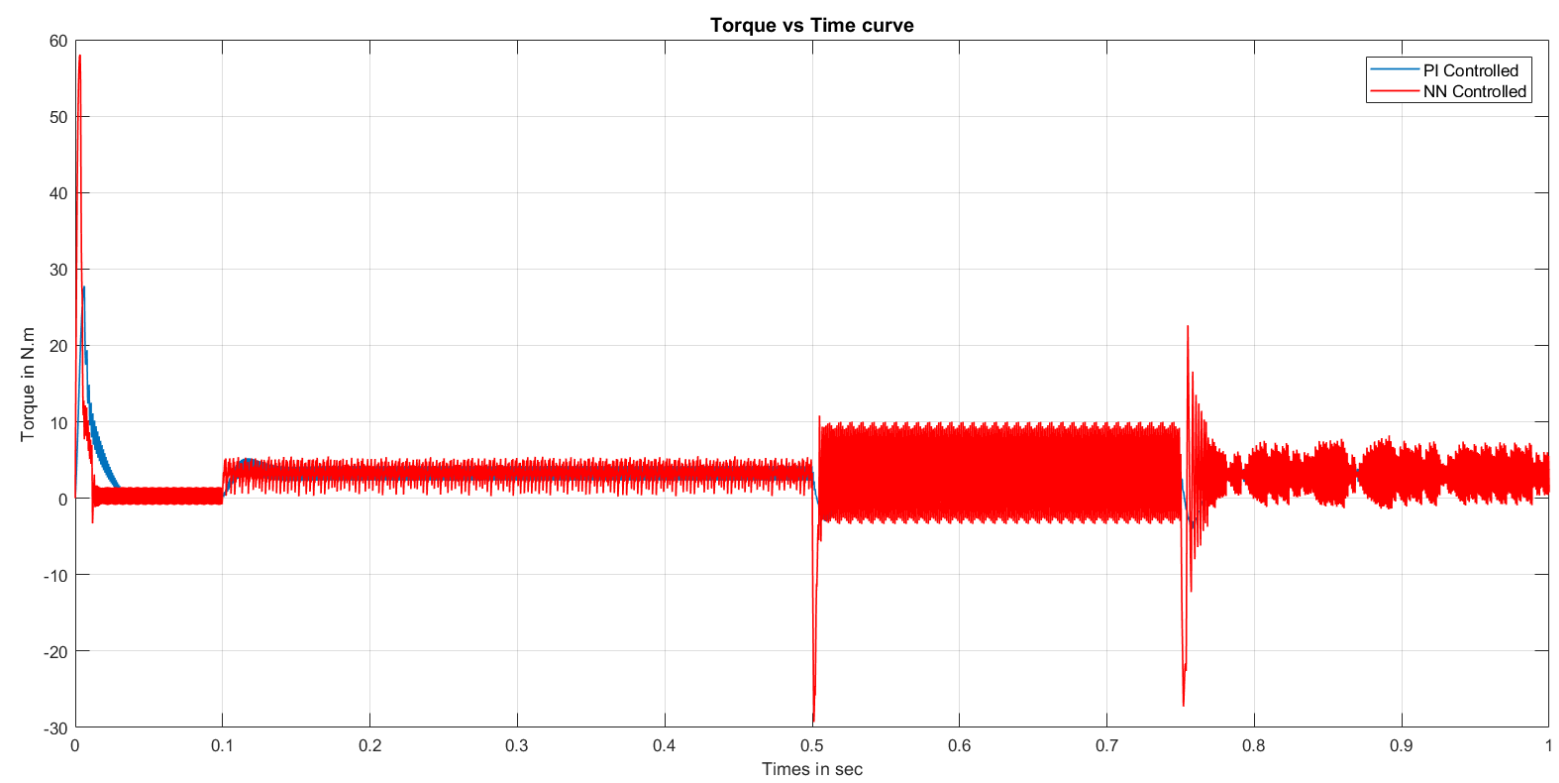

Figure 13. NN-PI Controller Torque Comparison

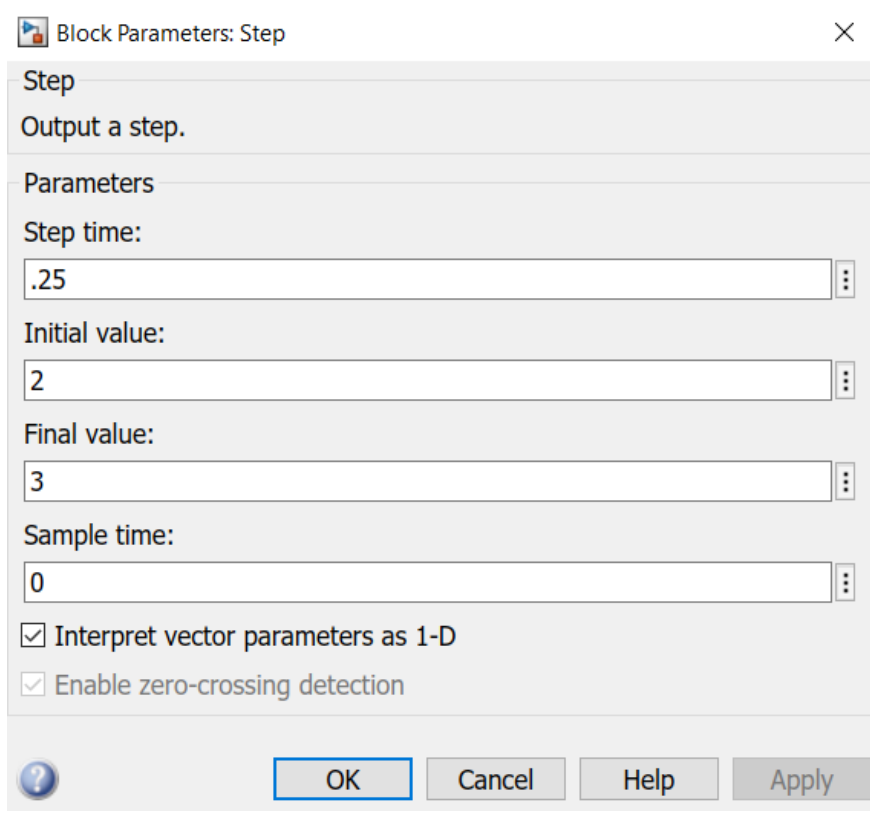

Figure 14. Change of load versus time

IRTIIE Vol. 6, No. 1, 2018 ISSN 1314-8788 (print), ISSN 1314-8796 (online), doi: 10.15547/artte.2018.01.003 


\section{ARTTE $Y$ Y}

Ipplied Resseirlores in Technics, Technologies and Educration Journal of the Faculty of Technics and Technologies, Trakia University https://sites.google.com/a/trakia-uni.bg/artte/

\section{CONCLUSION}

Based on the simulation results, it can be seen that the neural network based reference adaptive controller carries better performance parameters than the PI controller. In practical situations where the motor parameters change frequently, the MRAC responds better to the transient response. For this reason, the neural network based MRAC controller gave better results than the PI controllers in terms of optimum over-life and lower settling time. The realtime hardware-based test to verify the ability and superiority of the neural network based MRAC controller on the PI controller constitutes the future scope of the model presented here.

\section{APPENDICES}

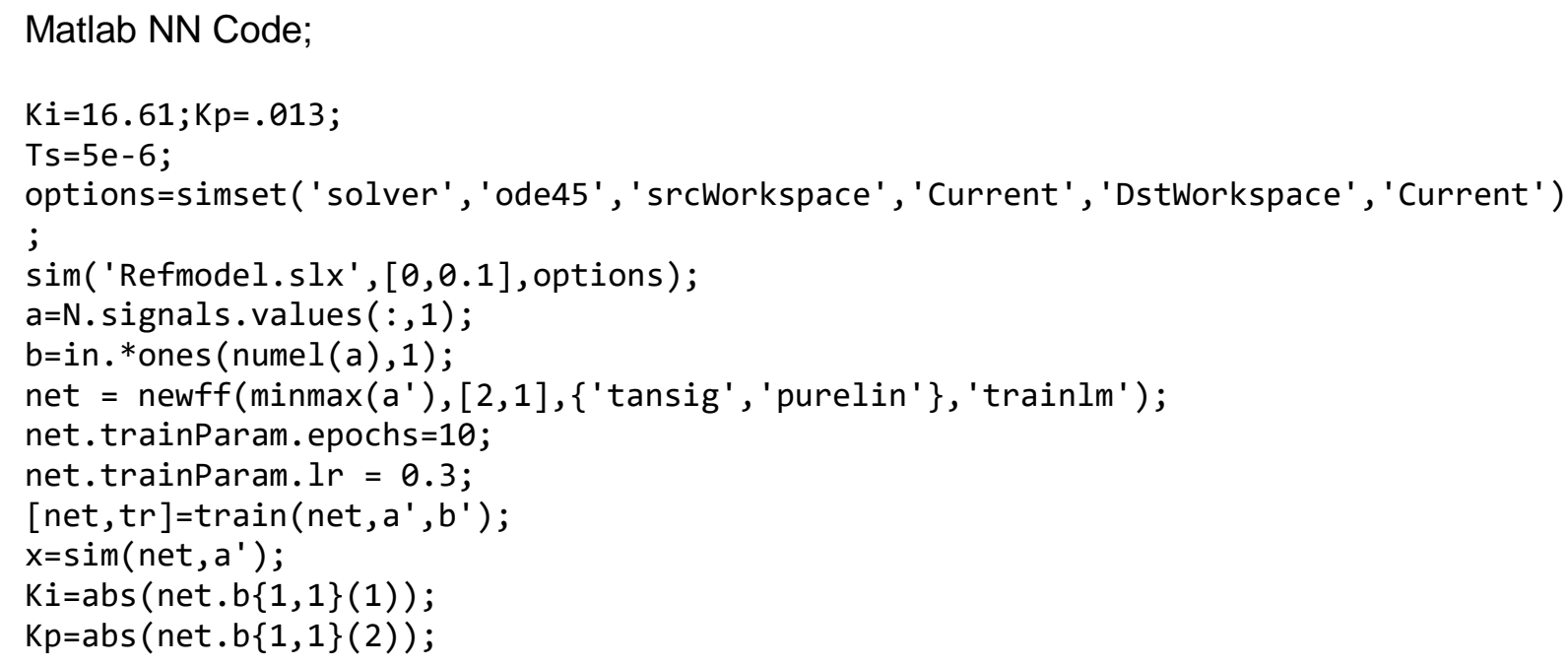

Reference variable speed settings:

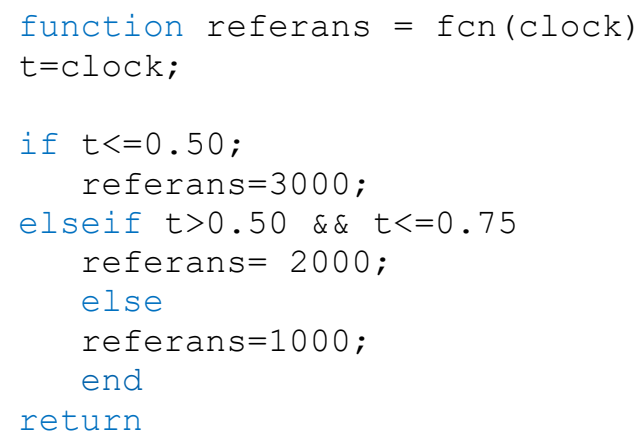

\section{REFERENCES}

[1] D. Montone. Temperature effects on motor performance. Pittman Motors and Ametek Precision Motion Control, USA, http://pittman-motors.com.

[2] Sodhganga. Modelling and parameter estimation on BLDC servo system, Chapter2, Department of Education, INFILBNET centre.

[3] J. R. Hendershot and T. J. E. Miller. Design of Brushless Permanent magnet Motors, Oxford, UK: Oxford Science,1994. 


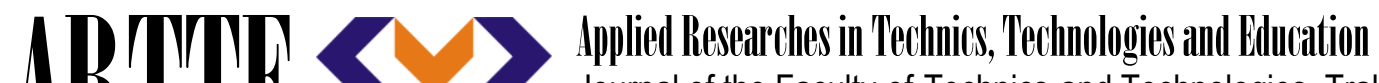 Journal of the Faculty of Technics and Technologies, Trakia University https://sites.google.com/a/trakia-uni.bg/artte/}

[4] P. Pillay and R. Krishnan. Modelling, Simulation and Analysis of Permanent-magnet Motor Drives, part 2: The brushless DC Motor Drive, IEEE Transactions on Industry Applications, vol.25, no.2, March/April 1989.

[5] I. J. Nagrath and M. Gopal. Control Systems Engineering (2nd ed.). Halsted Press, New York, NY, USA, 1982.

[6] A. K. Wallace and R. Spee. The effects of motor parameters on the performance of brushless DCdrive, IEEE Transactions on Power Electronics, vol.5, no. 1, pp. 2-8 January 1990.

[7] Varatharaju V. M., Mathur B. L., Udhyakumar K. Speed control of PMBLDC motor using MATLAB/Simulink and effects of load and inertia changes, 2010 2nd International Conference on Mechanical and Electrical Technology (ICMET) 10-12 Sept. 2010, pp.543-548.

[8] J. G. Ziegler and N. B. Nichols, Optimum settings for automatic controllers, Transactions of American Society of mechanical Engineers, Vol.64, 1942, pp.759- 768.

[9] M. Azizur Rahman, and M. Ashraful Hoque. On-Line Self-Tuning ANN-Based Speed Control of a PM DC Motor, IEEE/ASME Transactions on Mechatronics, vol. 2, no. 3, September 1997.

[10] S. Weerasooriya and M. El-Sharkawi. Identification and control of a dc motor using back-propagation neural networks, IEEE Trans. Energy Conversion, vol. 6, pp. 663-669, Dec. 1991. 